\title{
Interface Between National Ideologies and the Constitution of Pakistan
}

\author{
Shagufta Jabeen ${ }^{1} \&$ Wasima Shehzad ${ }^{1}$ \\ ${ }^{1}$ Air University Islamabad, Pakistan \\ Correspondence: Shagufta Jabeen,, Air University, Islamabad, Pakistan. E-mail: xaguftajabeen@yahoo.com
}

Received: April 3, 2018 Accepted: May 3, 2018 Online Published: May 23, 2018

doi:10.5539/ijel.v8n5p106 URL: https://doi.org/10.5539/ijel.v8n5p106

\begin{abstract}
Language of State Constitutions has mainly been studied from generic, linguistic, stylistic, and discursive perspectives, however, analyzing the same from ideological view point hasn't caught the eye or preference of most studies in general and in Pakistan in particular. The paper, with democratic concerns, concentrates on analyzing the presence of ideologies in the Constitution of Pakistan. It is exploratory in nature and analyzes genre of the Constitution of Pakistan (1973) to find out to what extent the constitution is loaded with ideological concepts and that what are the foci of such ideologies. It also delves into how ideologies are clothed in linguistic manifestation to form national views towards religion, politics, gender, power, education, rights, obligations, defense and various other "fields" and thus bring about socio-political effects. Genre analytical studies have taken a complete new turn after the introduction of elements of criticality and ideology, as in this paper. Precisely, the paper focuses on presence of ideologies in the text of the current Constitution of Pakistan and groups them under "fields of ideologies" which characterizes the constitutional genre under study. The study concludes by drawing attention to strong links between education and constitution which may be utilized to bring positive change in the society. The findings may potentially encourage similar CGA studies on constitutional genres and ideologies, around the globe.
\end{abstract}

Keywords: legal English, constitutional genre, constitution of Pakistan, ideologies, critical genre analysis (CGA)

\section{Introduction}

A Constitution usually carries a heavy threefold responsibility. Firstly, it must not overlook the factors resulting into making of the nation. Secondly, it must clearly envision the future, and thirdly, it has to be capable of determining the ways to reach the envisioned destination.

The study starts with the conviction that a national document, as important as Constitution, must be replete with certain ideologies, carefully structured and presented linguistically, impacting a national and public policies of the country, in this study Pakistan. Thus, critical genre analysis of the Constitution of Pakistan aims at finding instances of ideologies represented through language of the document. Constitutions are constructed to run the state affairs in well planned, systematic and regularized way. Any State Constitution is embedded in particular societies and reflects historical, political, cultural and societal background in its discourse. Similarly, it defines the contours of societies through its language. Though a Constitution is shaped by the representatives of society and shows plurality of national aspiration, it in turn also heavily impacts the social and political discourses and realities. Formally written or non-written (as Britain's Constitution) versions of Constitutions are constructed on ideologies of the people and also construe certain ideologies among people.

Literature on genre studies agrees that genres serve typical, socially recognized communicative purposes, yet we often find genres being exploited to convey private intentions (Bhatia, 1993, 1995). It is important at this point to distinguish the concept of criticality in CGA (Bhatia, 2002a, 2002b, 2004, 2006, 2008, 2017) from the notion of criticality in CDA. The element of "criticality" in CDA is concerned with identifying and evaluating societal actions that are considered to introduce social inequalities, injustices and disempowerment affecting certain sections of society, and then offering remedies to address these issues. However, in CGA criticality does not aim at finding faults with the system and "redressing power imbalances" (Bhatia, 2017, p. 27) in society. It rather, with "analytical rigor" (Bhatia, 2017, p. 28) maintains a neutral analysis of the content of the genre and means, to borrow Addison's (1712) words, "to focus on excellencies rather than imperfections" (Addison, 1712). 
Another change observed in studies related to constitutions is the increased importance of constitutionalism in different national societies across the globe (Thornhill, 2017).

The intricate nature of a formal genre (Shehzad, 2006) cannot be denied. The generic twitches increase even more in case of a highly formalized legal genre. The complicated process of framing a Constitution and the multitude of contributions from a wide array of political and social quarters make it almost impossible to analyze hidden intentions of the "author" of the Constitution under study. The same difficulty convinced Lawson (1994) to maintain that the private intentions of the authors (of American Constitution) are irrelevant, largely unknowable and likely to be diverse. So, he recommends that the functional role of the Constitution should be paid attention to instead of the private purposes of the lawgivers. Ideologies are clearly linked with, and impact, functional role of a constitution.

The study has identified certain areas of concentration of ideologies around which the whole text of the Constitution (1973) revolves. These areas or "fields of Constitutional ideologies" (Jabeen, 2017) are discussed in the following sections.

\section{Analysis and Discussion}

The 1973 Constitution of Pakistan, the third Constitution of the country, which was shaped shortly after the political crisis of 1970 and 1971, and claims to have represented the desire and will of the people of Pakistan. The study brings to surface numerous examples related to ideologies and ideals after an in-depth analysis of the text of Constitution. These examples or statements of ideals are grouped under 12 main categories. These main categories have been referred to in this study as fields of ideologies. Some of these fields contain significant presence of sub fields which have been placed under the main fields. Though, it was difficult to group some ideals under one field due to their overlapping nature, yet they have been placed in a field based on the contextual hints as found in the text of the Constitution.

One of the examples of statement of ideals in the Constitution is its Article 62 (1) which details "qualifications to be able to obtain membership of the Parliament". Clause 1 of the Article, in paragraphs (a), (b), and (c) states the conditions involving citizenship, age limit, enrollment as voter; however, paragraphs (d) and (e) of the same clause revolve around Islamic ideology. These conditions placed in para (d) require the potential member of the Parliament to possess "good character", and to be "not commonly known as one who violates Islamic Injunctions". Paragraph (e) requires him/her to be adequately knowledgeable about "Islamic teachings and practices obligatory duties prescribed by Islam" as well as abstaining from "major sins". Paragraph (f) of the clause enlists personality characteristics common across the globe, religions, and communities. These characteristics, related to ideals, can safely be called as universal positive personality traits. In the whole Article 62, qualifying phrases i.e. "good character" "adequate knowledge", "good moral reputation", and qualifying words i.e. "sagacious", "righteous", "non-profligate", "honest" and "ameen" are contextually relative and hence semantically vague, leading to multiple interpretations.

\subsection{Islamic Ideology and the Constitution (1973) of Pakistan}

The Constitution starts with a preamble which contains the gist of the philosophical and ideological notions discussed in the rest of the text. The Preamble briefly hints at the past and sums up the future direction set by the founders for the nation. The state name itself is reiteration of the ideals and philosophy discussed in the Pakistan Resolution of March, 1940. The State is declared an Islamic State and the constitution believes to have safeguarded Islamic ideology confidently. The Objectives Resolution though having remained preamble to three Constitutions of Pakistan was made part of the Constitution (1973) under Article 2-A in 1985.

After a few conditional clauses in beginning of the preamble, the pronoun "we", is used to describe the "people of Pakistan". The pronoun "we" is followed by qualifying words like "conscious", "cognizant", faithful", "dedicated", and "inspired" before declaring that "we" "do hereby, through our representatives in the National Assembly, adopt, enact and give to ourselves, this Constitution". The sentence taking place a little before the collective commitment is made, clearly requires the citizens of Pakistan, at any point in time in near and remote future, must be knowing about the "unremitting struggle of the people against oppression and tyranny", as they remain dedicated to the preservation of democracy.

The adjectives used for the people of Pakistan hint towards certain presuppositions and entailments. It presupposes that the people of Pakistan are Conscious, Cognizant, Faithful, Dedicated, and Inspired, with reference to the given context. This presupposition may be correct in the given time and space when Pakistan was still a newly established state and the people of Pakistan had lived through the sacrifices and hardships, in one way or the other to get independence. However, the same level of presupposition cannot be expected from 
the succeeding generations without making continuous efforts to make the coming generations conscious and cognizant of the "responsibility and sacrifices", as stated in the preamble.

The Resolution, highlights the principles of "democracy, freedom, equality, tolerance and social justice". These principles were strongly recommended to be observed in the Constitution as they have been enunciated by Islam (Liaqat Ali, 1949).

Article 1 of Part 1(Introductory) of the Constitution defines the territories of the Islamic Republic of Pakistan and authorizes Majlis-e-Shoora (Parliament) to, by law, admit into the "Federation, new States or areas on such terms and conditions as it thinks fit". Article 2 of the Constitution (1973) states, "Islam shall be the state religion". The Article reflects historical struggle, to have a separate state, which got materialized in 1947.

\subsubsection{Constitutional Safeguards for Islamic Ideology}

As mere statement of ideology is never enough to impact national thoughts, it is necessary to device certain ways to ensure anchorage of national or state ideology. The study came across certain clauses embedded in the constitution (1973) to protect Islamic ideology. One of the measures to safeguard Islamic ideology in the constitution is inclusion of the Resolution in it as has been discussed in the previous part.

Another strategy to safeguard the state ideology may be seen in the Schedule 3, linked with the Article 42, "Oath of President" which takes pledge from the office of President. The Schedule requires the president of Pakistan to promise under oath to "strive to preserve the Islamic Ideology which is the basis for the creation of Pakistan" and to "preserve, protect and defend the Constitution of the Islamic Republic of Pakistan" (Constitution, 1973). Similarly, oaths for the offices of Prime Minister, Federal Ministers of the State, Speaker of the national Assembly, deputy Speaker of the national Assembly, Member of National Assembly or senate, Governor of a Province, Chief minister or Provincial minister, Speaker of a Provincial Assembly, Deputy Speaker of a Provincial Assembly, and Member of a Provincial Assembly, in accordance with Articles 91, 92, 53, 53(2), (65), $102,130(5) \& 132(2), 53(2) \& 127,53(2) \& 127$, and $65 \& 127$ also contain the same promise to protect Islamic Ideology.

Yet, another measure taken is setting of the qualification criteria to become a parliamentarian. Article 62, in this connection, in its clause (1), in paragraph (g), determines qualification for becoming a member of the Parliament only if, among other conditions, "he has not, after the establishment of Pakistan, worked against the integrity of the country or opposed the ideology of Pakistan". Similarly, the point has been emphasized in Article 63 which is about disqualification for membership of the Parliament. Sub-clause (g) of clause (1) of the Article states that "a person shall be disqualified from being elected or chosen as, and hence from becoming, a member of the Majlis-e-Shoora (Parliament)", even if one of the series of conditions from (a) to (l) applies to him. These conditions are mainly about "propagating any opinion, or acting in any manner, prejudicial to the ideology of Pakistan".

Article 31 lays down the steps to enable the Muslims of Pakistan "individually and collectively, to order their lives in accordance with the fundamental principles and basic concepts of Islam" (Constitution, 1973).

Finally, to safe guard the Islamic Ideology, also called the ideology of Pakistan, the Council of Islamic Ideology was established to guide the President, or Governors of provinces or a Provincial Assembly, and to resolve ambiguities regarding conformity of some existing law with the injunctions of Islam. Part IX of the Constitution gives details on the composition etc. of the Islamic Council; Reference by Majlis-e-Shoora (Parliament) etc. to Islamic Council; Functions of Islamic Council; and Rules of procedure in Articles 228, 229, 230, and 231 respectively.

\subsection{Political Ideology}

To be able to stand on strong footing soon after independence, Pakistan needed to show much higher level of political maturity, not only in terms of legislation but also in terms of practice. Part III of the Constitution helps understand democracy as the political ideology of Pakistan. While talking about all the power and authority belonging to God, Liaqat Ali (1949) clearly distinguished between democracy and theocracy emphasizing the government of Pakistan a democracy in which the people, the recipients of the authority, would decide who they want to be governed by.

The Constitution of 1973 creates a parliamentary form of government and follows the principle of federalism. Which means the President of Pakistan is an elected citizen of Pakistan and that the state does not have hereditary or monarch based system of the government. Each president has to be elected and cannot be placed just out of hereditary succession order. Being the ceremonial head of state, the president has also to represent the unity of the state. In this connection Part IV explains mechanics of provincial assemblies and government, and 
Part V explains relations between Federation and Provinces. The first six articles of the Constitution outline the political system as federal parliamentary republic system, and Islam as its state religion. The Parliament cannot make any laws which may be repugnant or contrary to the Constitution, however the Constitution itself may be amended by a two-thirds majority in both the houses of the bicameral Parliament.

Detail of the structure of the government is given in Chapter 2 of the Part III "The Majlis-e-Shoora" which is about composition, duration and meetings of Parliament or the Majlis-e-Shoora. Its Articles 50 to 66 define the Majlis-e-Shoora and National Assembly, their respective compositions and duration, execution of the National Assembly through Speaker and Deputy Speaker, voting in the Assembly, summoning of one or both houses of the Parliament (the Majlis-e-Shoora), procedures for address by president, right to speak in the Majlis-e-Shoora, dissolution of the National Assembly, composition of the senate, election of the chairman and deputy chairman of the senate, other provisions related to the Senate, qualification and disqualification criteria for membership of the Majlis-e-Shoora, disqualification on grounds of defection, etc., resignation from seats, members' oaths, and privileges of members of the Senate.

This chapter is very important from the point of view of governance. The chapter discusses in detail the distribution plan of seats in National Assembly and presents this information in tabulated form. It also states general procedural details and legislative procedures respectively. The Articles 67-69 lay down general procedures regarding rules of the House, restriction on discussion in Majlis-e-Shoora /Parliament, proceedings and that members of the Majlis-e-Shoora are not to be inquired by Courts. Articles 70-88 lay down details of the legislative procedures regarding introduction and passing of Bills. Powers of the President to promulgate ordinances is given in the Article 89. The word "Majlis-e-Shoora" is used for the "Parliament" and means the "consultative assembly" was introduced by Ziaul Haq in 1985 on the government principles of early Islamic era ("Majlis-i-Shura replaces parliament", 2015)

\subsection{Power Dynamics and Constitution}

The study identifies Power Dynamics as a distinct field of ideology in the Constitution (1973). The Chairman of the constitution Committee linked the democracy with misuse of "power". He linked the dissolution of the first Constituent Assembly with the Constitution not having identified the source of power clearly. Power dynamics have been analyzed looking at the division of powers of the Government, power over language and expression, power with relation to the Armed Forces, and Power, Politics and Constitution.

\subsubsection{Governance and the Division of Powers}

Interpretation of Constitutional text has controlling effect on the decisions taken by judicial powers, legislative and executive branches of the government. Articles 141 to 144 are about legislative powers. However the power dynamics decided in the original Constitution have been modified from time to time especially during military rule time frames.

Division of powers among the three branches of the government, and powers and privileges of individual offices have been explained in Parts III, IV, and V of the Constitution in detail. Division of powers at different levels has been ensured through mechanism of advices and counselling. For example, under the Article 58, the President has the power to dissolve the National Assembly, however his powers have been kept under check by conditioning the decision to the advice by the PM and the National Assembly (NA) and further conditioning the enactment of decision with the time frame. All the provinces get represented at the National Assembly on the basis of their demographics and play active role in decision making of the parliament. $18^{\text {th }}$ amendment brought a major reform in the institutional structure by sharing the powers vertically through Articles 90 and 139(2). The distribution of power has been ensured to be trickled down to local level to enable the political leaders at local level to determine solutions to local issues. These, local decisions, however are guided by the state Constitution and policies.

The Constitution also has a mechanism of exercising check on the utilization of powers. Article 48 is an example of such measures. Its Clause (1) makes clear that "in the exercise of his functions, the President shall act [on and] in accordance with the advice of the Cabinet or the Prime Minister". The powers of Review and counsel are also vested in different Constitutional bodies e.g. Council of Common Interest and National Economic Council under the Articles 153 and 156.

\subsubsection{Power over Language and Expression}

Power of the Constitution over language can best be understood by analyzing constitutional amendments. As and a lesser known example the study points towards omission of word "freely" by General Zia in 1985 from the text objective resolution as given in the preamble. The original piece of the text was, "Wherein adequate provision 
shall be made for the minorities freely to profess and practice their religions and develop their cultures". However, after a lot of criticism, the change was reverted and the word was placed back in the text (as told by Justice Ramday during a telephonic interview conducted for this study, 2017).

From a punctuation mark to complete chunks of discourse may be altered, through amendments, to convey varied, or preferred, meanings. In this regard, Jabeen (2017) has pointed out interesting findings after undertaking a detailed textual/genre analysis of the Constitution (1973) of Pakistan.

Another example of the constitutional power over use of language is to use the constitutional words to bring about serious results. It is due to these undefined terms that certain Articles and clauses are relentlessly and purposefully used to exploit specific political phenomena and personalities in Pakistan. Very recent example is the charges, among many other, against the elected and still serving Prime Minister Nawaz Sharif for not being "ameen" (trustworthy). The Prime minister was accused of having undeclared and unjustified assets in foreign countries. The opposition used the same plea to demand disqualification of the PM from membership of the Parliament.

The word "adequately" is another example of ambiguous or vague expression. The word has been used 10 times (in Preamble, Articles 27, 38(b), 62(1)(e),199, and 138(1)(a), in the Constitution to avoid making absolute commitment.

It may safely be assumed that adequacy in most of the above situations may be determined by the prime minister or other competent body. Ironically, however, the prime minister himself/herself is supposed to have adequate knowledge of Islamic teachings and practices to be able to decide judiciously about such matters. The condition of have adequate knowledge to determine adequacy of "provision", "opportunity", "representation" and "livelihood" adds to the complexity of the notion.

In today's world of wide awareness it is necessary that a democratic way of making or amending the constitution is adopted. Also the processes to amend the Constitution need to be followed in true sense to yield a better level of adoption and understanding. The draft bills not only must be made public but also ratification addresses be made by the concerned political offices to take the citizens on board.

\subsubsection{Power, Politics and Constitution}

A Constitution is all about guiding the state affairs and is controlling in nature to ensure adherence to it in socio-political spheres of the life of the citizens. This legitimate power, however, cannot be vested in one person, on the pattern of monarch. This power is considered "a sacred trust, entrusted to us by God for the purpose of being exercised in the service of man so that it does not become an agency for tyranny or selfishness" (Khan, 1949) and it is for the people to decide who to vest this authority in.

Due to very political nature of the subject and resulting from, what I call, "religio-political" pressures, the article 260 (3-b) is referred to by numerous analysts as a political decision. The Article defining non-Muslims also includes Ahmadis for the first time. Indeed the question remains unanswered as to why Ahmadis were part of Muslim community since ever until this Constitution. It is not easy to deduce exact reasons behind this Constitutional Article and to conclude if it was a political move to devastate this community due to their being in strong financial state and political, administrative positions or pressure by religious groups on the government. According to Peirce and James (1870) taking a pragmatic stance means to be aware that the meaning of a proposition lie in observable practical consequences. In this connection, changes in defining certain groups and communities do not sound innocent.

\subsubsection{Power with Relation to the Armed Forces}

Military in any country is usually the most powerful organization. In fact power and military may sometimes be used as synonyms or as mutually exchangeable words. The military power is legitimately not only used in war times but also to maintain law and order within the state. The positive utilization of this power during peacetimes is summed up by Janowitz (1977) that the military is an important agent of change especially in postcolonial societies because:

Chapter 2 of Part XII of the Constitution (1973) states Constitutional provisions regarding Command of the Armed Forces, Oath of Armed Forces, and Functions of Armed Forces in Articles 243, 244, and 245 respectively.

Powers vested in the Armed Forces may also be understood from Article 63 (g) under which a Member of Parliament is disqualified if he has been convicted by "a court of competent jurisdiction for propagating any opinion, or acting in any manner, prejudicial to... the Armed Forces of Pakistan...". "Use of language" in terms of criticism on the Armed Forces has institutionally and constitutionally been banned thus through Article 63(g). 
Acting of the Armed Forces in aid of civil power was legitimized in 1977 through Article 245 (2). Time and reason of insertion of these Clauses must be of great interest to the researchers interested in the area of political powers, manipulation of powers, and uses and abuses of powers.

\subsection{Society as Envisaged in the Constitution (1973)}

In this section, ideological views as presented and safeguarded by the Constitution have been discussed. This field of ideologies contains subfields too, as proposed by the study. These subfields are discussed below.

\subsubsection{Social Justice \& Civic Life}

The expression "social justice" has been used 3 times in the text of the Constitution. Social justice has been stressed upon twice in the preamble and once in Article 37. In clause (d) of Article 37, agreeing to the dictum "justice delayed is justice denied", the Constitution reads that the state "shall ensure inexpensive and expeditious justice" to eradicate social evils.

Moreover, the word "political justice" has also been used in the preamble to the Constitution. A preamble to the Constitution determines the foci of the Constitution and hence has the controlling power. Presence of the expressions Social Justice and Political Justice means the State's preference for these areas.

The Article 37 has ten clauses under it and all focus on some dimension of social justice and eradication of evils from society. It uses strong expressions which sound very promising. It uses strong verbs followed by a series of nominal phrases. In clause (d) of Article 37, agreeing to the dictum "justice delayed is justice denied", the Constitution reads that the state "shall ensure inexpensive and expeditious justice" to eradicate social evils. Clause (g) of the Article explicitly resolves to "prevent prostitution, gambling and taking of injurious drugs, printing, publication, circulation and display of obscene literature and advertisements". Except clauses (a) and (h), rest of the clauses of the Article 37 are for all the citizens of Pakistan irrespective of their religious and sectarian affiliations. The state promises made in this Article are hedged around with certain conditions.

The word "justice" alone has been used six times with reference to education. Out of six, five places talk about educating citizens and once about removing illiteracy. This overwhelming stress on education clearly puts forward the State's ideology of justice and its firm belief that only "education" is the safest and fastest way to remove injustices from society. The second most common factor linked with social and political justice is "employment". Positive engagement of the individuals naturally stops them from being involved in unrewarding and unwanted activities. Yet another way of ensuring justice and removing social evils is prevention from social evils. Unemployment being the root cause of social evils has been pointed out directly at least four times in the text of the constitution.

\subsubsection{Paradigm of Pluralism}

It is important to mention here that that the Constitution (1973) predominantly uses the word "people" for the citizens of Pakistan, irrespective of the religion. There are total 33 instances of the word "people" used in the under analysis text. The usage of the word ensures political sovereignty of "the people" of Pakistan. The analysis gets support from the observations made by Sardar Abdur Rab Nishtar when he pointed out that the emphasis in the Objectives Resolution was placed on "the people", "the right of the people", "the representatives of the people" and "the authority of the people" ( in Shah, 2007, p. 55).

Use of the word "Muslim" in 17 instances, in its singular form is mainly as a qualifier. The word qualifies other words like "judges", "citizens", "world", "personal law", "countries", "family law" etc. The word is also used as part of compound noun i.e. "Muslim League". Other instances take place as part of oaths and once as part of definition of Muslim.

The word "Muslims" has been used total 5 times in the Constitution (1973) in the Preamble, Articles 31, 31(2), 230, and the annexed Objectives Resolution to refer to the following in the respective order- a) the state to enable Muslims to live their lives according to the teachings of Islam; b) the state to provide Muslims Islamic way of life; c) the State to endeavor for compulsory education of Islamiat, promote unity, and proper organization of zakat, ushr, auqaf and mosques; d) the Islamic council to recommend ways and means to the Parliament and provincial assemblies to enable the Muslims in Pakistan to live according to Islamic teachings; e) reiteration of "a", respectively.

\subsubsection{Social Inclusion}

A unique concept related to inclusion is that of "special representation". Article 32 "Promotion of local Government institutions of the Constitution" stresses the inclusion of peasants, workers and women in local government institution composed of elected representatives of the areas. 
A deeper analysis yields the state's implied recognition of these as underprivileged parts of the society, hence special recognition!. Jabeen (2017) notices two different modes or veins of inclusion circulating throughout the text of the Constitution described as:

\section{i. Exemption \\ ii. Specification}

Inclusion here means taking care of the differences of varied communities living in Pakistan. With this understanding, exemption is not exclusion here. It rather means to exempt certain communities from a common Constitutional practice keeping in mind their right to live according to their faith and beliefs. One example of exemption takes place in Article 37(h) which exempts non-Muslim citizens of Pakistan from prevention on the consumption of alcohol. In this example the religious and cultural differences of non-Muslim communities are constitutionally embraced by exempting them from otherwise banned practices for the Muslim community.

Examples of specification or specific provision can be observed in form of reserved political seats for non-Muslims. The categories for members represent certain communities or groups as distinct ones. Articles 32, as discussed above is a good example of specification.

The analysis finds out that another group of citizens exempted and specified is based on gender i.e. women of Pakistan. The observation also gets strengthened finding out frequent collocation between the words "non-Muslims" and "women". The element of inclusion may be analyzed at two levels- i) sectarian differences, ii) gender differences (Jabeen, 2017) while discussing the Article 228 (3)(d). The Article related to the "Composition of the Council", states that "at least one member is a woman".

\subsubsection{Religious Majority}

Islam being the religion of majority in Pakistan, the Constitution does not favor sectarian divisions and does not talk about any Muslim sect in particular. Clause (b) of Article 20, clarifies that the "expression 'Quran and Sunnah' shall mean the Quran and Sunnah as interpreted by that sect". It further explains that "Nothing in this Part shall affect the personal laws of non-Muslim citizens or their status as citizens". Though the word democracy is not used in this Part even once, the Part has strong linguistic cues to embody the spirit of democracy.

\subsubsection{Religious Minorities}

The Constitution (1973) uses the word "minority" is a general expression to describe statistical value of population and not as a derogatory word. The Preamble safeguards rights of the non-Muslims as "Wherein adequate provision shall be made for the minorities freely to profess and practice their religions and develop their cultures". The Constitution protects the rights of minorities under Article 36. The Article promises that "The State shall safeguard the legitimate rights and interests of minorities, including their due representation in the Federal and Provincial services" (Constitution, 1973). The Minority citizens of Pakistan are entitled to vote under Article 51 of the Constitution (1973) if they satisfy the general laid down without making and distinction between Muslims and non-Muslims. Moreover, out of 342 sets in the National Assembly ten are reserved for non-Muslims (Article 51(4)) constituency for them being the whole country (Article 51 (6)(c)).

Rights promised to the Non-Muslim citizens or minorities include "freedom to profess religion and to manage religious institutions" maintains that "every religious denomination and every sect thereof shall have the right to establish, maintain and manage its religious institutions" (Article 20(b). However they cannot under the Article 41(2) be the head of the state or the Prime Minsiter.

The study finds a delicate blend of binding and liberating in Article 227 and its explanation. It binds the current and future state laws to be in congruence with Islamic Provisions but it also adjusts citizens with different beliefs from Muslin community as well as Non-Muslim communities both.

\subsection{Global Dimension and Social Competitiveness}

In an actively changing world of economy, socio-political conditions, international coalitions and relation, the Constitutions needs to shoulder the responsibility of preparing its people to cope well with internally and externally in the global era. Article 40 of the Constitution is about strengthening bonds with Muslim world and promoting international peace. The Article recognizes the importance of fraternal relations with the Muslim and international world. The Article highlights the relations at three levels:

i) Muslim Countries (based on Islamic unity)

ii) Asia, Africa and Latin America (due to common interests) 
iii) All nations (based on good will and friendly relations)

The Article further emphasizes "international peace" and encourages "the settlement of international disputes by peaceful means". The Constitutional considerations about peace are discussed in the next section.

\subsection{Peace and Human Rights}

The ideologies related to Global dimension of competent States can also be related to the State aspirations regarding peace and respect of human rights within the state and outside both. In this regard Article 38 highlights the need of "Promotion of social and economic well-being of the people". Also the preamble states it as one of the aspirations of the People of Pakistan to be able to "make their full contribution towards international peace and progress and happiness of humanity".

The word "peace" has been used 10 times in the Constitution to convey meanings with relation to international peace, tranquility, security and progress. Article 149 "directions to the provinces in certain cases" under its clause (4) dictates that the executive authority of the Provinces "is to be exercised for the purpose of preventing any grave menace to the peace or tranquility or economic life of Pakistan or any part thereof". The emphasis in the clause is obvious from the use of "shall" and "is to". Other Articles on measures regarding ensuring peace in society include Article 159, Article 247 (4) and (5), and Article 258.

The text of the Constitution shows use of equal linguistic expression of the rights for all communities of Pakistan. It lays considerable stress on the necessity of international and internal peace. The word "peace" has been used 15 times in the text out of which four times it speaks of international peace and progress. For in-depth analysis of the handling of the concept of "peace" in the Constitution, the lexical item "peace" is studied in the context of neighboring words.

\subsection{Fundamental Rights}

Fundamental Rights comprise over a number of important economic and social rights. Purpose of the government is to protect these rights vested through the Constitution. Similarly, Judiciary has the role to protect and enforce these rights. This section will have a critical look at the fundamental rights promised in the Constitution, what ought to be and what human right are actually available do not the objective of this study.

The fundamental rights vested in the Constitution (1973) are in close lines with those spoken by Quaid during his different speeches and addresses. These values include Islamic concepts of forgiveness, equality, and peace which may also be called universally desirable values. It is important to refer here briefly to Jinnah's political disposition. His understanding of the socio-political makeup of the British-India, and his own political acumen had strong impact of the British legal education and law practice, "association with liberal politics in India, a deep understanding of the rise and fall of the Muslims in history and inspirations from egalitarianism, socio-economic justice and reformism in the teachings and principles of Islam" (Rizvi, 2014). Quaid's struggles, though late, but took turn to materialize what Iqbal said, "self-government within the British empire or without the British empire" (1930).

It may be safely inferred that though the state will not be able to provide all the rights within limited resources, it promises to facilitate the citizens to achieve them with the help of different laws. The rights have been conferred upon using different modes i.e. safeguarding; protecting; giving freedom to do, prohibiting from, and acknowledging right to have / do. For example, Article 20 confers the right to freedom of speech, and further maintains that "No person shall be deprived of life or liberty saves in accordance with law".

The rights, however, are "subject to law, public order and morality". First two of the three conditions are relatively clear but the third condition has as many interpretations as many religions and Muslim sects in the country. Use of the word "morality" which at times is linked with public morality in the whole text has vagueness about it. No checklist is provided or criteria made known, to determine morality or immorality of an action.

\subsection{Language Matters}

The Constitution gives due attention to a variety of language related issues. There are 12 references made to languages in the text of the Constitution. Article 251(1) is of supreme importance in this regard. It goes "The national language of Pakistan is Urdu, and arrangements shall be made for its being used for official and other purposes within fifteen years from the commencing day". Urdu as official language would have added to the efficiency of official work and would have reduced the amount of time spent in solving linguistic riddles in official documents. It would have also spread awareness among common citizens on official issues and would have simplified procedural ambiguities of the world of professions. According to the Article, Urdu language 
should have become, or at least should have been on its way to become, a commonly used language in offices, industry, and educational institutions by the year 1988 .

\subsection{Economy and Financial Resources}

Handling of financial resources is an important part of State political ideology and has been addressed in Part VI of the Constitution. The Part deals with "Finance, Property, Contracts and Suits" and Article 160 especially talks about "National Finance Commission" (NFC). However there is no mention in the chapter of any efforts or regulation to keep the national debt under control or to determine a ceiling debt for the country Islam's debt. Under the same Article an Award, namely National Finance Commission Award, has been enacted since 1951 to address financial imbalances in bot vertical and horizontal directions. In the competition between the federal and provincial governments to get the higher share of the award of NFC, Punjab has secured -out of seven total awards given since 1951. Each award lasts for the duration of five years. Population density and poverty have become added parameters to decide about awarding the commission. It may safely be predicted that distribution of finances will also be impacted by the results of the census bringing Article 160 in the fold of potential future amendments.

Eighteenth amendment of the Constitution brought changes in almost 102 out of 260 total Articles of the Constitution (1973). Due to the devolution of federal powers, it impacted all ministries and divisions. Due to its link with the different handling of the financial resources, it also brought in the need for better financial management.

\subsection{Gender Dimension}

The language used in the Constitution is apparently gender neutral and does not distinguish the citizens on the basis of gender unless "the gender has to be specified". For example in section 34 which talks about full participation of women in national life. All are to comply with the Constitution. The word "person" is used to talk about citizens. Following is the example from Article 4 (1) which is about right of individuals to be dealt with in accordance with law, etc.:

"To enjoy the protection of law and to be treated in accordance with law is the inalienable right of every citizen, wherever he may be, and of every other person for the time being within Pakistan."

Categories of "exemption and specification" are not only limited to the non-Muslim citizens, but also to women. Interestingly, women have not been further specified as Muslims and non-Muslims. Representation of women is ensured through Constitutional provisions, some of which are discussed below.

The apparently deceptively gender neutral discourse is replete with the hidden assumptions on gender. The pronoun "he" is used in the text to refer to both, the "citizen", and "person" and is used to function as a gender neutral expression. However, use of "he" as a gender specific pronoun in most of the Articles / Clauses contrast against this supposition. The words "Speaker", "Deputy Speaker", "President", Prime minister", "Minister" and "Governor" though gender free have been made gender specific by using the pronoun "he" following them. The pronoun "he" here gender specifies the position by eliminating the possibility of "she" to be the president.

Article 63(b), paragraph (ii), explicitly uses the pronoun "she" when stating down the qualification for membership of the Parliament. The paragraph is about potential female parliament members who must have been enrolled as voter in any area of her choice, for election to a seat reserved for women.

However, this problem can very easily be traced to the nature and structure of the language too in which the Constitution has been written. English language does not provide a third person, singular, gender free pronoun other than "it" or "them" in recent efforts to make politically correct expressions. This limitation of English language results into similar vague or exploited limitations. If so, then some foot note on interpretation of gender specific pronouns should have been added.

Commenting on the enabling Clause and the following Clause guaranteeing cultural freedom to minorities, Leonard Binder described it "as a step to enshrine the two nation theory in the future Constitution of Pakistan" and "it would certainly give the government more authority in religious matters than is usual in western or westernized states".

\subsection{Education and Allied Issues}

Constitution (1973) through its Article 37 (b) \& (c) in respective order promised that " the State shall remove illiteracy and provide free and compulsory secondary education within the minimum possible period"; and that it shall "make technical and professional education generally available and higher education equally accessible by all on the basis of merit". 
$25 \mathrm{~A}$ also demands the provinces to formulate their own legislation and policies regarding education. The Islamabad Capital Territory (ICT) and Sindh province have already enacted legislation in this regards, while others are currently in the process of finalizing their respective legislations. Balochistan province has also promulgated an Ordinance to declare free education a responsibility of the government. This Ordinance, which is a provisional law, is yet to be passed by the Provincial Assembly of Balochistan (Unesdoc, P. 07).

Article 37(f) is quite promising as it talks about enabling people of "different areas through education, training, agricultural and industrial development and other methods" so that they are able to fully participate in social activities to serve the country. Use of the word "shall" shows emphasis of the state promise.

\subsection{Miscellaneous Foci}

Thirty eight Acts have been passed by the Punjab Assembly regarding law and order in the province. To study socio-cultural background of the document it is important to understand the prevailing socio-political scenario and to describe very briefly views in favor and against it in the phases of preparation and implementation. Analysis in this section concludes that Constitution of Pakistan is not just a collection or presentation of ideology. It strives to instantiate citizens' principles and beliefs.

Article 25 of the Constitution which states that "all citizens are equal before law", is said to contradict with its own Article 2 which announces that "Islam shall be the state religion". It is among impossibilities to declare one religion as state religion and yet to offer fascinating accounts of equal rights among all citizens.

\section{Conclusion}

The study aimed to analyze the constitutional genre from ideological perspective in the geo-political context of Pakistan. Ideals are predominantly socially relative concepts. When these ideals get legal expression in form of Constitution, they become both more emphatic and more ambiguous forming up national ideologies. The Constitution (1973) of Pakistan enshrines different kinds of ideologies which have been described according to their thematic unity under the following 12 different "fields of ideology".

Table 1. Fields of ideologies in the Constitution (1973) of Pakistan

\begin{tabular}{|c|c|c|}
\hline Sr No. & Main fields of Ideologies & Sub-Fields of Ideologies \\
\hline 1 & Islamic Ideology & $\begin{array}{ll}\text { - } & \text { Pakistan \& Islamic Ideology } \\
\text { - } & \text { Safeguards for Islamic Ideology } \\
\text { - } & \text { The Council of Islamic Ideology }\end{array}$ \\
\hline 2 & Political Ideology & - \\
\hline 3 & Power Dynamics and the Constitution (1973) & $\begin{array}{ll}\text { - } & \text { Governance and the Division of Powers } \\
\text { - } & \text { Power over Language and expression } \\
\text { - } & \text { Power, Politics and Constitution } \\
\text { - } & \text { Power with Relation to the Armed Forces }\end{array}$ \\
\hline 4 & Society as envisaged in the Constitution (1973) & $\begin{array}{ll}\text { - } & \text { Social justice \& Civic life } \\
\text { - } & \text { Paradigm of Pluralism } \\
\text { - } & \text { Social Inclusion } \\
\text { - } & \text { Religious Majority } \\
\text { - } & \text { Religious Minorities }\end{array}$ \\
\hline 5 & Global Dimension and Social Competitiveness & - \\
\hline 6 & Peace and Human Rights (inland and abroad) & - \\
\hline 7 & Fundamental Rights & - \\
\hline 8 & Language Matters & - \\
\hline 9 & Economy and Financial Resources & - \\
\hline 10 & Gender Dimension & - \\
\hline 11 & Education and Allied Issues & - \\
\hline 12 & Miscellaneous Foci & - \\
\hline
\end{tabular}

These ideologies not only shape the rules of business, but also add the elements of conditionality for certain offices or to carry out official / constitutional businesses. The same also adds to the vulnerability of the relevant offices to be held accountable on breach of the required conditions related to these ideals. On the other hand, knowledge of these 12 fields of constitutional ideologies will enable the educated citizens to have balanced view towards society and different segments therein. The study, keeping in consideration the current geopolitical issues related to peace and stability of democracies, emphasizes the need to revive the sanctity of the Constitution and to ensure the rule and supremacy of parliamentarian system to ensure proper implementation of 
policies anchored in the Constitution of Pakistan. It is necessary to prepare the citizens to be able to participate in the matters of governance by opining about it and by contributing through purposeful feedback. Such education is bound to enable citizens to make informed decisions about the day to day civic life. They can contribute to sustainability of national development only if they are confident of their civic responsibilities and constitutional rights and are educated on the above highlighted ideologies. This is when and where National Education Policy comes to play its role in terms of deciding how to educate people on the subject matter. There is an immediate demand to review National Education Policy of Pakistan to ensure citizens are educated about the constitutional ideologies of the country. The awareness is also anticipated to control radicalization of youth in the country.Finally, Linguistic and law related researches in Pakistan, need to exhibit more serious concerns by exploring local issues, thus adding to the number of researches to be utilized at the level of decision and policy making.

\section{References}

Addison, J. (1712). "Literary Criticism" in Spectator. No 291, February 2, 1712. Retrieved from http://archive.twoaspirinsandacomedy.com/spectator/spectator.php?line=291

American Psychological Association. (1972). Ethical standards of psychologists. Washington, DC: American Psychological Association.

Bhatia V. K. (1993). Analysing Genre - Language Use in Professional Settings. London: Longman.

Bhatia, V. K. (1997). Genre-Mixing in Academic Introduction. English for Specific Purposes. New York, NY: Guilford Press.

Bhatia, V. K. (2002a). Applied Genre analysis: A Multi-Perspective Model. London: Longman.

Bhatia, V. K. (2002b). Professional Discourse: Towards a Multidimensional Approach and Shared Practice. City University of Hong Kong Press.

Bhatia, V. K. (2004). Worlds of Written Discourse: A Genre-Based View. London: Continuum.

Bhatia, V. K. (2006). Genres and Styles in World English. Malden, MA: Blackwell.

Bhatia, V. K. (2008). Genre Analysis, ESP and Professional Practice. English for Specific Purposes. London: Longman.

Bhatia, V. K. (2017). Critical genre analysis: Investigating interdiscursive performance in professional practice. New York: Routledge.

Jabeen, S. (2017). Critical Genre Analysis of the Constitution of Pakistan and Reflection of Constitutional Ideologies in the National Education Policy of Pakistan (Unpublished doctoral dissertation). Air University Islamabad, Pakistan.

Janowitz, M (1977). Military Institutions and Coercion in the Developing Nations: the military in the political development of new nations. Chicago: University of Chicago Press.

Lawson, G. (1994). The Rise and Rise of the Administrative State. Harvard Law Review, 107(6), 1231-1254. https://doi.org/10.2307/1341842

Liaqat Ali Khan: on the objectives resolution, March 9, 1949. Retrieved from https://www.scribd.com/document/101966744/Speech-of-Liaquat-Ali-Khan-on-the-Objectives-ResolutionMarch-9-1949

Shehzad, W. (2006). Outlining purposes, stating the nature of the present research, and listing research questions or hypotheses in academic papers. Language and Computers, 60(1), 227-241.

Unesco Report. Retrieved from http://unesdoc.unesco.org/images/0022/002297 /229718E.pdf

\section{Copyrights}

Copyright for this article is retained by the author, with first publication rights granted to the journal.

This is an open-access article distributed under the terms and conditions of the Creative Commons Attribution license (http://creativecommons.org/licenses/by/4.0/). 